
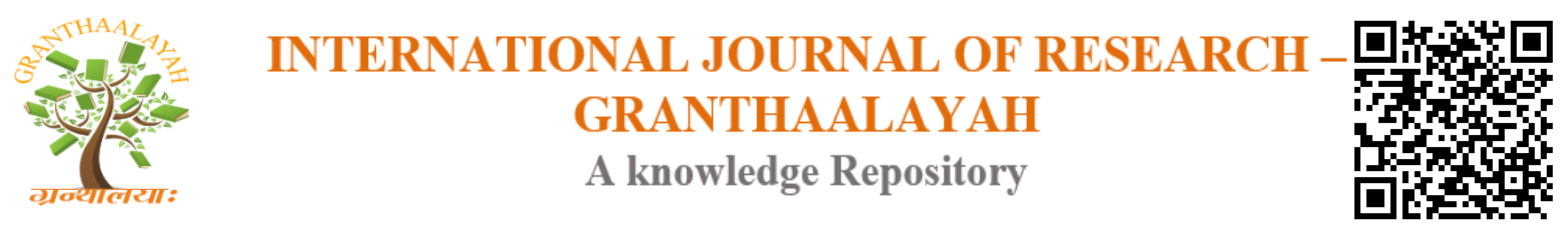

Science

\title{
A MONITORING SYSTEM FOR PETROLEUM PIPELINE VANDALISM IN THE NIGER DELTA REGION OF NIGERIA
}

\author{
Franklin O. Okorodudu *1, Philip O. Okorodudu ${ }^{2}$, Lawrence O. Atumah ${ }^{3}$ \\ ${ }^{* 1}$ Department of Computer Science, Delta State Polytechnics, Otefe-Oghara, Delta State, \\ Nigeria \\ ${ }^{2}$ Department of Electrical Engineering, University of Nigeria, Nsukka, Enugu State, Nigeria \\ ${ }^{3}$ Department of Science Laboratory Technology, Delta State Polytechnics, Otefe-Oghara, Delta \\ State, Nigeria
}

\begin{abstract}
Petroleum pipeline vandalism has, over the years, become a torn in the flesh of successive administrations in Nigeria as the nation losses 12 billion dollars yearly to pipeline vandalism related issues. There is an urgent need to permanently address the rising scourge in the nation. In this study, an approach for synthesizing a monitoring system to curtain pipeline vandalism in the Niger Delta Region of Nigeria is presented. The design was done in stages starting with the power supply subsystem and culminates in the simulation of the whole subsystems to give the overall monitoring system. The simulation of the subsystems was done using the procedural programming application Proteus 8. Most of the components used in the design of each sub systems was according to design specifications from data book with alternatives used in cases where they are unavailable. The overall system was tested to perform the required task of monitoring pipelines. It is found that the overall system is able to monitor petroleum pipelines and reduce acts of vandalism on the nation's pipeline topology.
\end{abstract}

Keywords: Monitoring; Niger Delta Region of Nigeria; Pipeline Vandalism; Spillage; Topology.

Cite This Article: Franklin O. Okorodudu, Philip O. Okorodudu, And Lawrence O. Atumah. (2018). "A MONITORING SYSTEM FOR PETROLEUM PIPELINE VANDALISM IN THE NIGER DELTA REGION OF NIGERIA.” International Journal of Research - Granthaalayah, 6(6), 139-150. https://doi.org/10.29121/granthaalayah.v6.i6.2018.1359.

\section{Introduction}

Petroleum pipeline vandalism has, over the years, become a torn in the flesh of successive administrations in Nigeria as the nation losses 12 billion dollars yearly to pipeline vandalism related issues [1]. It has been reported that Nigeria has been robbed of over 130 million barrels of crude oil since the resurgence of militancy in 2015 [2] 
Before middle 2016, Nigeria was the largest producer of petroleum in Africa and among the top five oil producing member nations of the Organization of petroleum Exporting Countries (OPEC) [3]. However, due to pipeline vandalism, oil production dropped significantly making the country to lose its position as the number one oil producer in the continent. In the first quarter of 2013 for instance, the daily crude oil production stood at between 1.86 and 2.1 million barrels per day against the estimated 2.48 million barrels that it was estimated to produce during that time.

Also, according to OPEC monthly report for March, 2017, Nigeria lost the top spot of oil producer status to Angola as it crude oil production fell by 156,900 barrels per day in the period under review. According to the report, the country produced 1.426 million bpd in February of 2017 down to the 1.269 bpd it produced in March, 2017 [4]. These loses, the body said, is a consequence of the disruption in the supply of the commodity occasioned by acts of militancy and insurgency in the oil rich region of Niger Delta.

In agreement with the assertion put forward by the oil cartel, the Nigeria's minister of state for petroleum resources, Ibe Kachikwu stated recently that between 2015 and 2016, the country's crude oil production dropped by 800,000 barrels per day. In 2015 , the nation produced an average of 2.2 million barrels per day down to the 1.4 million barrels per day that it produced in 2016 [5].

Speaking recently at the 2016 Fiscal liquidity Assessment Committee Retreat in Abuja, the NNPC Group Managing Director Maikanti Baru also noted that the equivalent loss of the petroleum industry in 2016 alone could have been used to build a new 7,000MW power plant; new 350kpd refinery; over 30 per cent of National budget; and a new 1,700 kilometres pipeline [6]

Thus, the effects of pipeline vandalism on the nations' economy is enormous and far reaching. Aside the economic loss that acts of vandalism results into, other areas of human endeavour are also severely affected. In the process of trying to scoop petroleum products, pipelines may be damaged while most of the fuels are spilled on the environment. The damaged pipelines may go unnoticed for some time while the cost of repairs is huge. Petroleum products spilled on the environment wreak havoc destroying sources of drinking water, killing aquatic and terrestrial animals and plants and rendering farmlands unproductive.

[7] noted that the activities of pipeline vandalism are more than Nigeria losing money from production, costly repairs and clean-ups as well as facility downtime, it is a sad story of consistent pollution of farmlands and rivers by people who are not bothered by the effects of their actions on the environment.

To address the rising scourge of vandalism in the country, the Federal government set up a joint task force to provide security to the nations' oil industry. In 2013, the joint task force report was alarming and indicting, the report indicated that 3, 778 illegal refineries were destroyed within the period. It also said eight vessels were seized in the process with 120 barges, 878 boats, 178 pumps, 5238 surface tanks, 606 pumping machines and 626 outbound engines belonging to the vandals confiscated. Most alarming was the report that cabals in top positions were behind the spate of vandalism that the country experienced during the period [8]. 
These efforts notwithstanding, pipeline vandalism has been on the increase as vandals and their sponsors seem not to be deterred by efforts of government and other agencies to put a stop to their nefarious activities. Petroleum pipeline vandalism is a big stumbling block to Nigeria achieving its set out collective objectives. This study aims to design a monitoring system that would be able to curtain activities of pipeline vandalism in the oil rich region of Niger Delta.

\section{An Overview of the Niger Delta Region of Nigeria}

The Niger Delta is covered by the natural delta of the Niger River and the areas to the east and west. Geographically, the Niger Delta is located in the southern part of Nigeria often referred to as the south-south with a few more addition from the east and west. The expanded Niger Delta region is made up of nine states with 185 local governments covering at least 40 ethnic nationalities speaking 250 languages and dialects and a population of around 45 million [9], [10].

The region occupies a surface area of about 112,110 square kilometers, representing about $12 \%$ of Nigeria's total surface area [10]. It cuts across 800 oil producing communities with an extension network of over 900 oil producing wells and several petroleum product related facilities [11]. The Niger Delta is described as the largest wetland in Africa and among the three largest in the world with a complex terrain [12]. The eco-system of the area is acknowledged as one of the most diverse and richest, highly supportive of human life. The region is host to huge deposits of oil and gas, with its exploitation accounting for over 80 percent of the country's foreign exchange earnings [12].

The Niger Delta is located is the world's second largest delta with a coastline of about $450 \mathrm{~km}$ which ends at Imo river entrance [13]. Difficult topography encourages people to gather in small communities. Of the estimated 13,329 settlements in the Niger Delta, approximately 94 percent have populations of less than 5000 people [14].

The Niger Delta region has been the center of international controversy over waste of natural resources, devastating pollution, genocide and human rights violations. At its peak, about 2.5 million barrels of crude oil could be extracted from the Niger Delta in a day. In early 2012, it was estimated that 38 billion barrels of crude oil was yet untapped in the region [15]. Before vandalism and oil theft took centre stage in the region, Nigeria accounted for the largest natural gas reserve in Africa and the second largest oil reserve in Africa and until recently, it was the continents' primary oil producer [16].

\section{Implication of Pipeline Vandalism in Nigeria}

Petroleum pipeline vandalism has become too frequent in recent times. The consequences and implications of this frequency would be difficult to grapple with in years to come. Increased vandalism of pipelines has made the Niger Delta to become an ecological wasteland. Major rivers have been polluted just as farmlands have been made unproductive. It was observed by [17] that farmlands in the region are under acid rain just as spillage and carbon dioxide emissions in the region are among the highest in the world. 
In middle 2016 and early 2017, the nation experienced one of its worst fuel scarcity in history. Even though there seem to be some form of fuel stability now, normalcy has not been restored as the cost of transportation, occasioned by increase in the pump price of fuel is still high.

Perhaps a major implication of pipeline vandalism is the degree to which it affects the energy sector of the country. There is barely any part of the country that enjoys uninterrupted power supply as distribution companies now load shed to at least give a little amount of energy to consumers [18]. Those with generating sets are finding it difficult to fuel them as the economic situation in the country continues to rear its ugly head.

Also, with the vandalization of NNPC pipeline which resulted in its closure sometimes in 2016, the nation became poorer by N1.7 billion in just four days while repairs of damaged pipelines will take millions to repair and weeks to fix [19]

Thus, Incessant and frequent pipeline vandalism have resulted in the continued decline of the nation's national earnings which has translated into a low gross domestic product loss and a reduction in government revenue. While the actual figure that the country loses daily due to acts of vandalism is unquantifiable, it is estimated that the nation lost 165 billion naira to petroleum product theft in the space of three years [20]

Implications of pipeline vandalism on the ecosystem is unprecedented. For every petroleum spillage that occurs in the country, the environment bears the burden of absorbing such spillages. These spillages go into the soil and degrade the soil thus affecting the rate of farm produce as well as contaminating drinking water for both human and animals [21]. The lands are even more affected as it tarnishes the vegetation of an area and sends animals that leave in their natural habitats parking as a result of the destruction of their places of abode.

Sea plants are not left as spillages on the sea and water bodies block out light and prevent photosynthesis [1]. In this situation, sea plants and animals have limited oxygen to breath due to the non-replenishment of the already used oxygen. There is thus the need to find a lasting solution to address the rising vandalism in the region.

\section{Component Design}

The system design has both hardware, software and user requirements. The hardware subsystem includes the hardware units used to realize the visible test-bed for the monitoring system for use in the region.

The hardware sub system is categorized into seven (7) major units namely:

1) The Power Supply Unit

2) The Comparator Unit

3) The Microcontroller Unit

4) The Switching Unit

5) The Transceiver Unit

6) The Base Station/Control Room Unit and

7) The pipeline pressure sensor 


\subsection{Hardware Sub-System}

\subsubsection{Power Supply Subsystem}

The power supply unit was designed from first principle. It consists of a 220v/9v step down transformer with IN4001 diodes connected in a bridge rectification format as shown in the overall circuit design of Fig. 3. The capacitor rating is $25 \mathrm{v}$ by $2200 \mathrm{uF}$. The transformer steps down $220 / 240 \mathrm{~V}$ to $12 \mathrm{~V} \mathrm{AC}$ and then convert it to DC to feed the DC supply voltage used in controlling the circuit. Other components of the power supply unit include transistors and relays.

The regulators produce the $9 \mathrm{~V}$ and $5 \mathrm{~V}$ used to power the rest of the circuit. In most designs, assumptions are always made to ensure certain conditions are accomplished. The assumed values hence help in calculating the variables.

The following assumptions were made in the design of the system:

Input frequency $=50 \mathrm{~Hz}$

Secondary voltage of the power transformer $=9 \mathrm{Vrms}$

Diode voltage $=0.7 \mathrm{~V}$. (Silicon semiconductor)

using $V_{\max }=V_{r \operatorname{ms}} x \sqrt{2}$

We get $V_{\text {max }}=9 x \sqrt{2}=12.726 \mathrm{~V}$

This value helps in calculating the peak inverse voltage of the rectifying diodes which was calculated to be $12.3 \mathrm{~V}$.

\subsubsection{The Comparator Unit}

The comparator is similar to the operational amplifier but with two input voltages and one output voltage that depends on voltage at any of the positive or negative terminal. In the design of this model, LM324N was used because of its ability to accommodate a low voltage power supply. It is a 14-pin integrated circuit that consist of four independent operational amplifiers in a single package.

In the design of the comparator circuit, three operational amplifiers were used with each of the operational amplifier connected to a pipeline with the help of a $5 \mathrm{~V}$ voltage regulator that helped to determine when the operational amplifier will send signals to the switching circuits and whether an alarm would be triggered or not depending on the voltage received by either of the inputs of the operational amplifier.

\subsubsection{The Microcontroller Unit}

The microcontroller unit is the brain behind the designed system. The microcontroller chosen for this function in the design is the PIC16F 628A, it is a product of Microchips. The functions of the microcontroller-16F628A include amongst others: to turn on the system automatically when power is connected, to interpret signals, to send an alert signal to the base station in case it senses an 
intruder by making the sender Bluetooth device to switch ON with the help of the switches, to notify the control room of intrusion using the Liquid Crystal Display (LCD) to show the actual point (s) of intrusion and to clear the transceiver's screen and to relay audio signals around petroleum pipelines to the base station.

\subsubsection{The Switching Unit}

A 9V relay and a C1815 transistor were used as switches in the designed model. The relay switch can be divided into two parts: the input and the output. In the 5-terminal relay switch used, two terminals were used to give the input $9 \mathrm{~V} \mathrm{DC}$ voltage as the operating voltage of the relay while the remaining three terminals are used to connect the high voltage $\mathrm{AC}$ circuit. The $\mathrm{C} 1815$ transistor conducts current across the collector-emitter path when a voltage is applied to the base while it switches off when there is no voltage applied to the base.

\subsubsection{The Transceiver Unit}

The transceiver operates at a frequency of $900 \mathrm{MHz}$. This is the operating frequency of a GSM phone. The transceiver is a modified GSM phone. Through it, a wireless information exchange can be achieved. The mode of communication here is similar to that of FM receivers but it is not a broadcast. The transceiver, which is a GSM device is a modified Nokia (or a Bluetooth device) android phone. It is hosted on a network through a SIM module. Every SIM module has a unique identification number. Through this identification number, it can send and receive data on the local and global GSM network transmitter and receiver. The transceiver unit transmits and receives signals at a certain frequency.

\subsubsection{The Control Room}

The Control room or base station has a central server which has been programmed to send signals to various terminals to alert them of any intrusion. This is done with the aid of wiring sensors that have been wound round pipelines in remote locations as shown in Fig. 1 below.

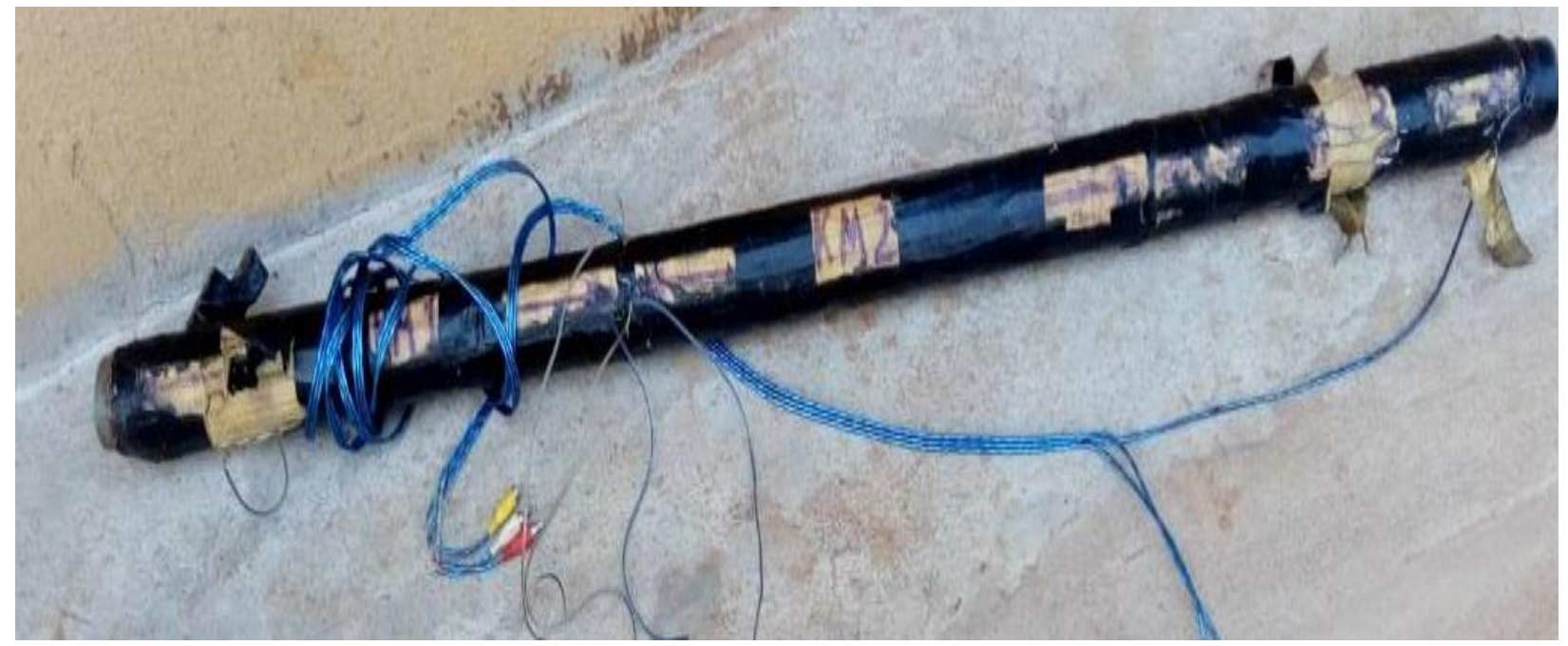

Figure 1: Sample petroleum pipeline coated with sensor wires 
The alarm is set to go off if trespassers or vandals go beyond a certain limit nearer to the pipeline. The sensors wound round the pipelines acts as the actuator to trigger the alarm at the control room or base station once it detects the presence of people or animals. Light Dependent Resistors (LDR) was used in consonant with other resistors in the design so as to make it work properly at night. The designed circuit is put in a box and placed in any network provider mask area where it will have the best of network at all times for quick and uninterrupted transmission of information to the control room for action in cases of intrusion. The overall block diagram of the designed system is as shown in Fig. 2 below

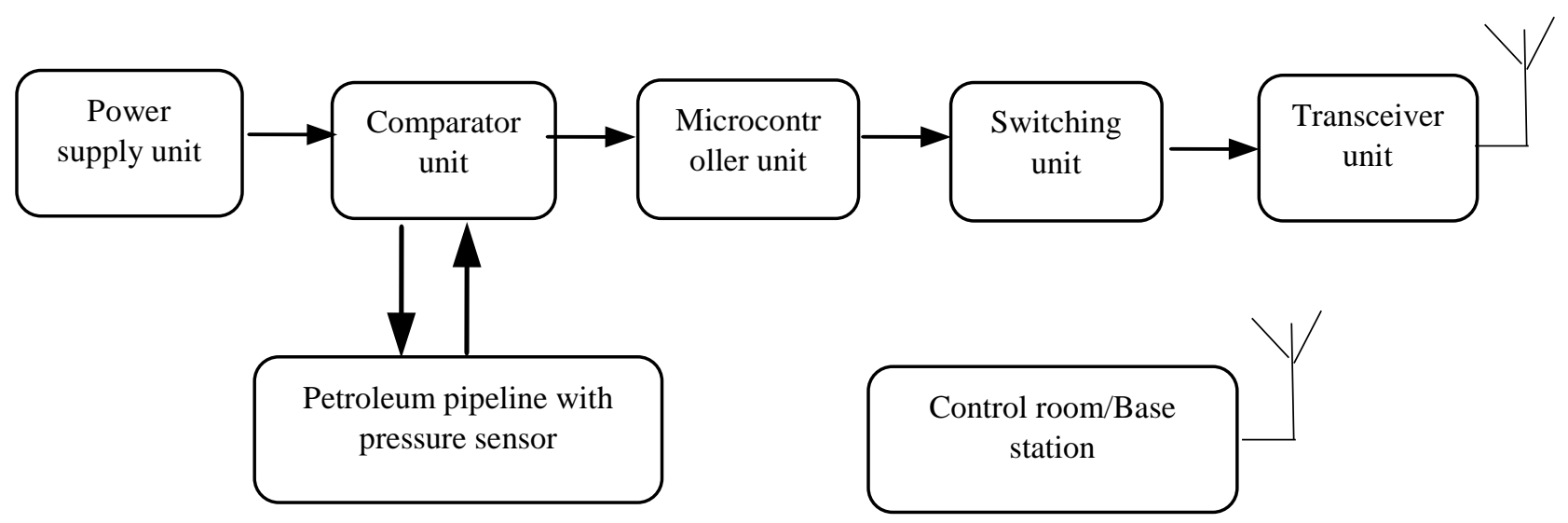

Figure 2: Block diagram of the designed petroleum spillage monitoring model

\subsection{Software Requirement of the Model}

The software sub - system include the software units used to realize the sensor that initialize the process, data transfers from the deployed visible test-bed to the designated mobile phones and an online server and clients at the base station of the designed system. The programming language chosen is Visual Studio, because it is easy to use in writing programs for Windows. It simply gives you maximum control over your computer. The designed circuit is to be located within the premises of any network service provider while the control room and or base station is to be at the head office of any of the multinational oil company that has petroleum pipeline network. The mode of operation of the designed circuit is wireless and will be using the power provided by the service provider mask which is constantly on.

\subsection{User Requirement of the Model}

The user requirement requires that the users are conversant with the use of the computer system as well as being able to read, write and interpret instructions properly. The user requirement is required at the base station where the user is expected to understand the basic operations of the computer system and a basic knowledge of Microsoft access so as to be able to interpret different signals. 


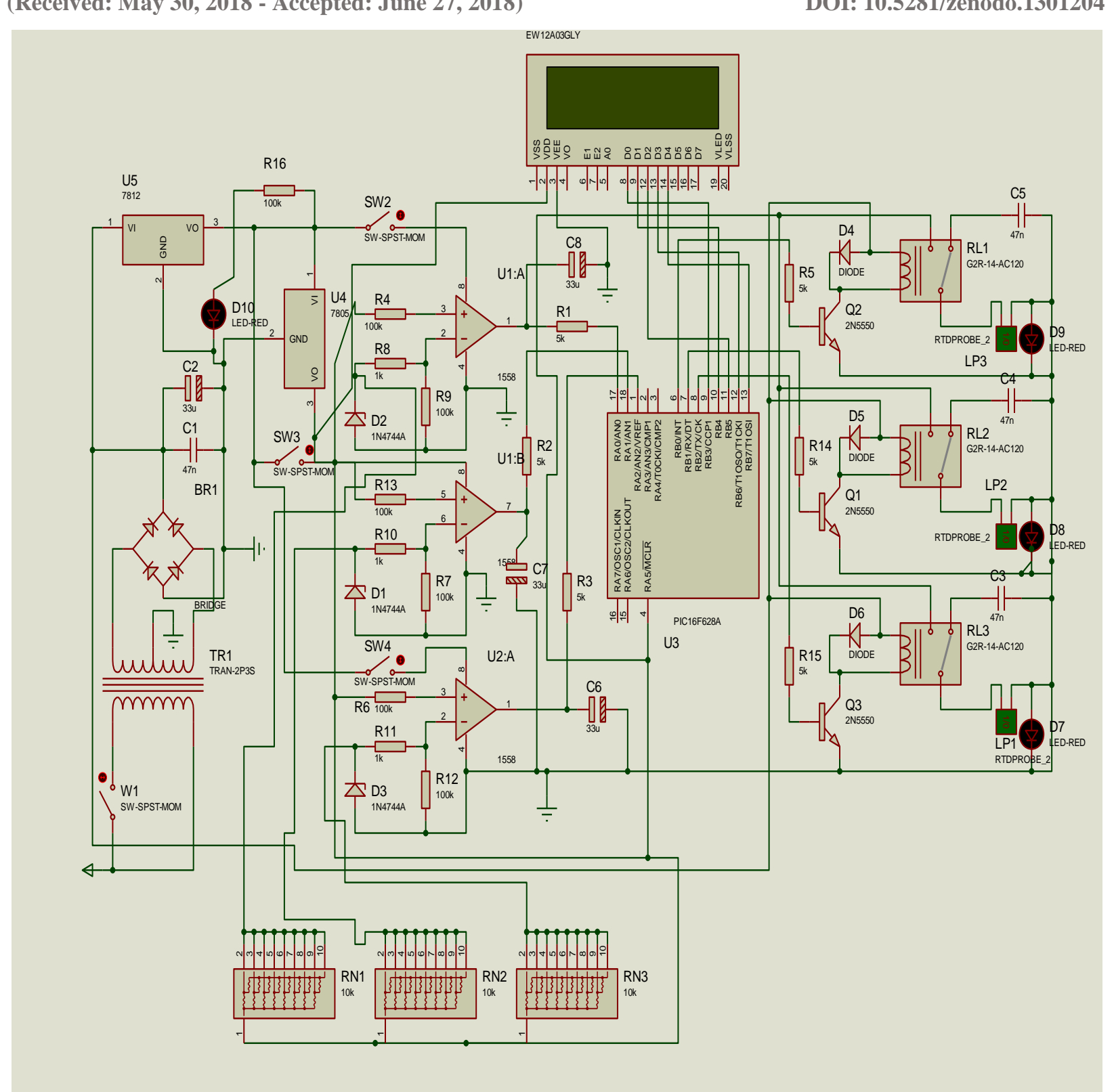

Figure 3: overall circuit design of the petroleum monitoring system

\section{System Algorithm}

The sequence of stages of the design is as enumerated below:

Start

Monitor the line

If there is a break

Comparator output goes high

Microcontroller

LCD display, switching devices active

Transceiver active, LED confirms

Rescue team, line safe 


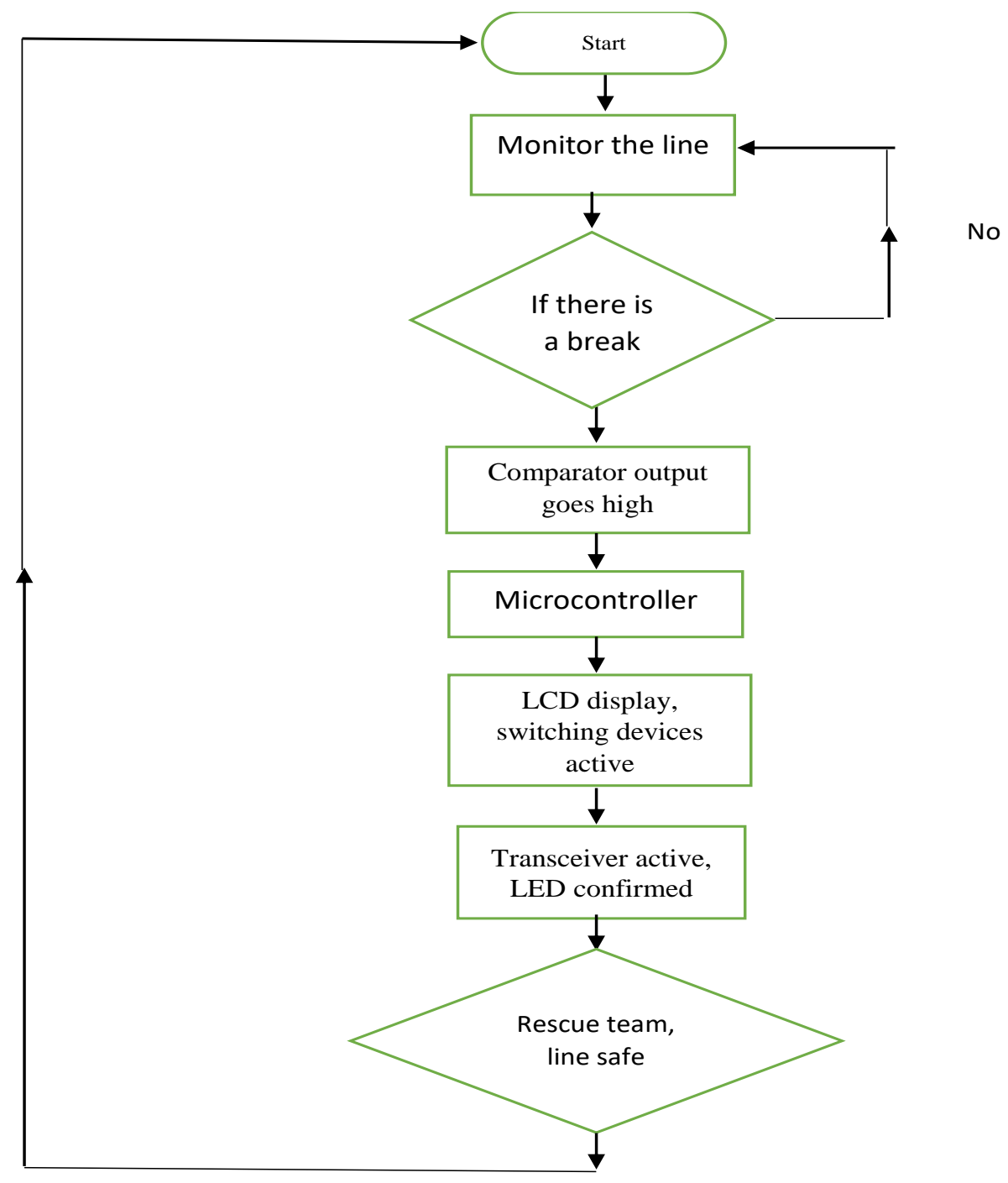

Figure 4: System algorithm

\section{Results and Discussion}

The complete unit was tested and implemented after the design. The implementation was done by bringing together all the parts and packaging them in a circuit box, referred to here as the control room, which was designed to transmit and receive signals. The petroleum pipeline is coated with sensor wires and to the cell phone of every team leader within the geographical area where petroleum pipelines are laid. The transmission looked good with the help of telecommunication mask and a battery and generator that was used to power the device in the absence of electricity from public power supply. The system is set to read data along the petroleum pipelines, checking within the set perimeter for intruders by activating the detection sensor then set alarm if any action within the set perimeter is said to be true. Table 1 shows the table of tested values obtained when the system was tested as soon as the sensored wire is tempered with, it shows on the screen the nature of damage done to the petroleum pipeline. Some of the results obtained while running simulation test using Microsoft access is shown in Fig. 6 indicating the exact pipeline that has been tampered with. Fig. 5 shows the visual studio display of the process leading to the display of the 
vandalized pipeline while Fig. 7 shows a prototype of the designed petroleum pipeline monitoring system put in a casing and placed at the base station

Table 1: Table showing result of tested value

\begin{tabular}{|c|c|c|}
\hline Pipeline & Sender Bluetooth & Receiver Bluetooth \\
\hline Km 1 vandalized & $\mathrm{ON}$ & Connected \\
\hline Km 2 vandalized & $\mathrm{ON}$ & Connected \\
\hline Km 3 vandalized & $\mathrm{ON}$ & Connected \\
\hline Km 1 vandalized & OFF & Not Connected \\
\hline $\mathrm{Km} 2$ vandalized & OFF & Not Connected \\
\hline Km 3 vandalized & OFF & NOT Connected \\
\hline
\end{tabular}

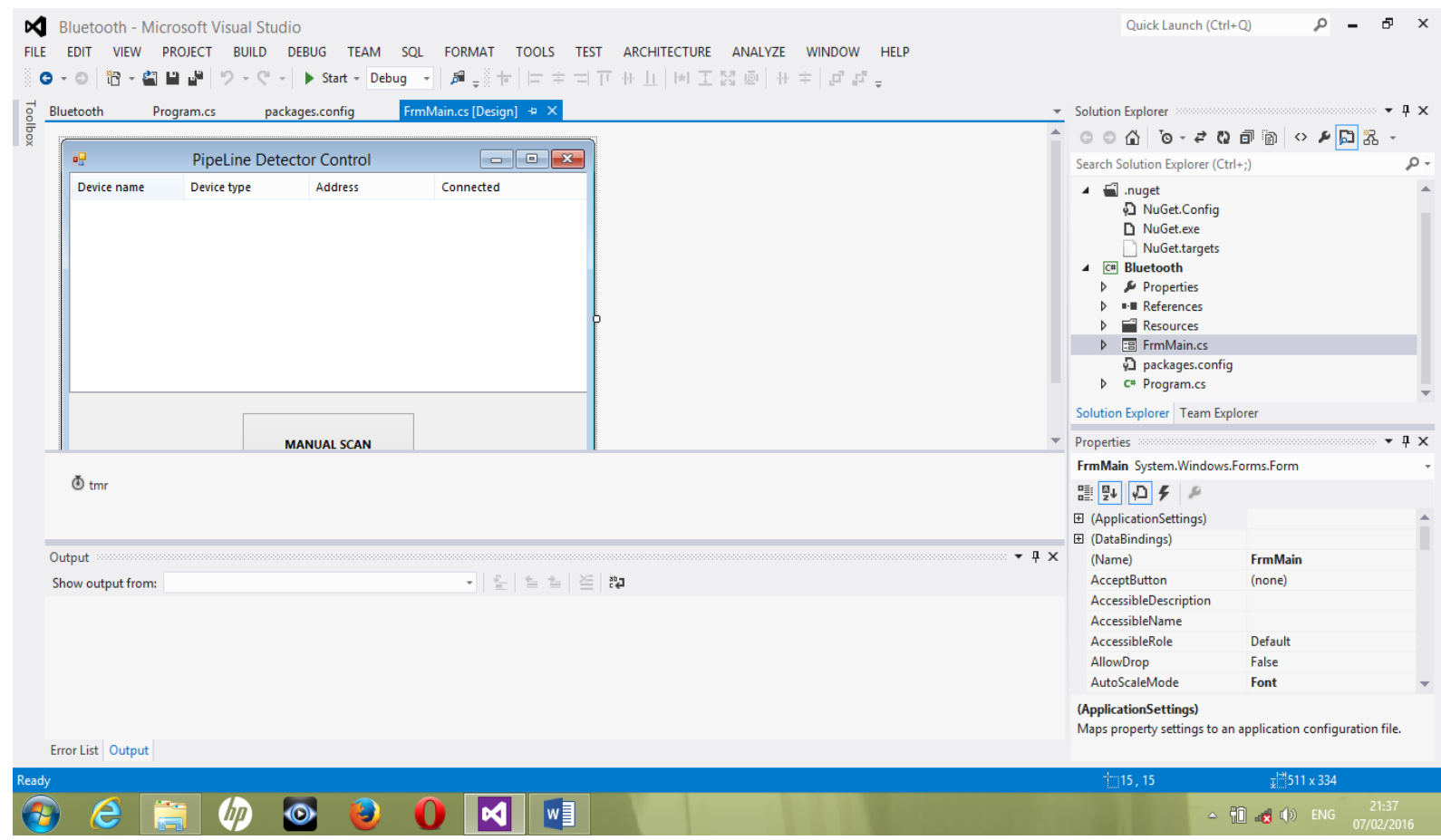

Figure 5: showing the output process screen on Microsoft visual studio

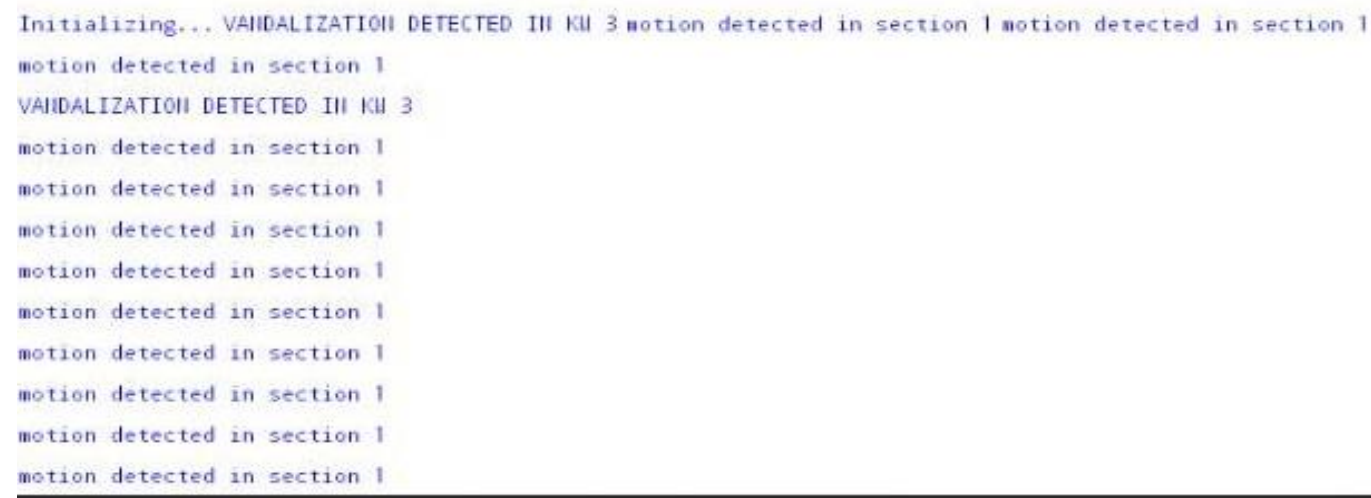

Figure 6: Information displayed on screen when the sensor senses activities on a pipeline 


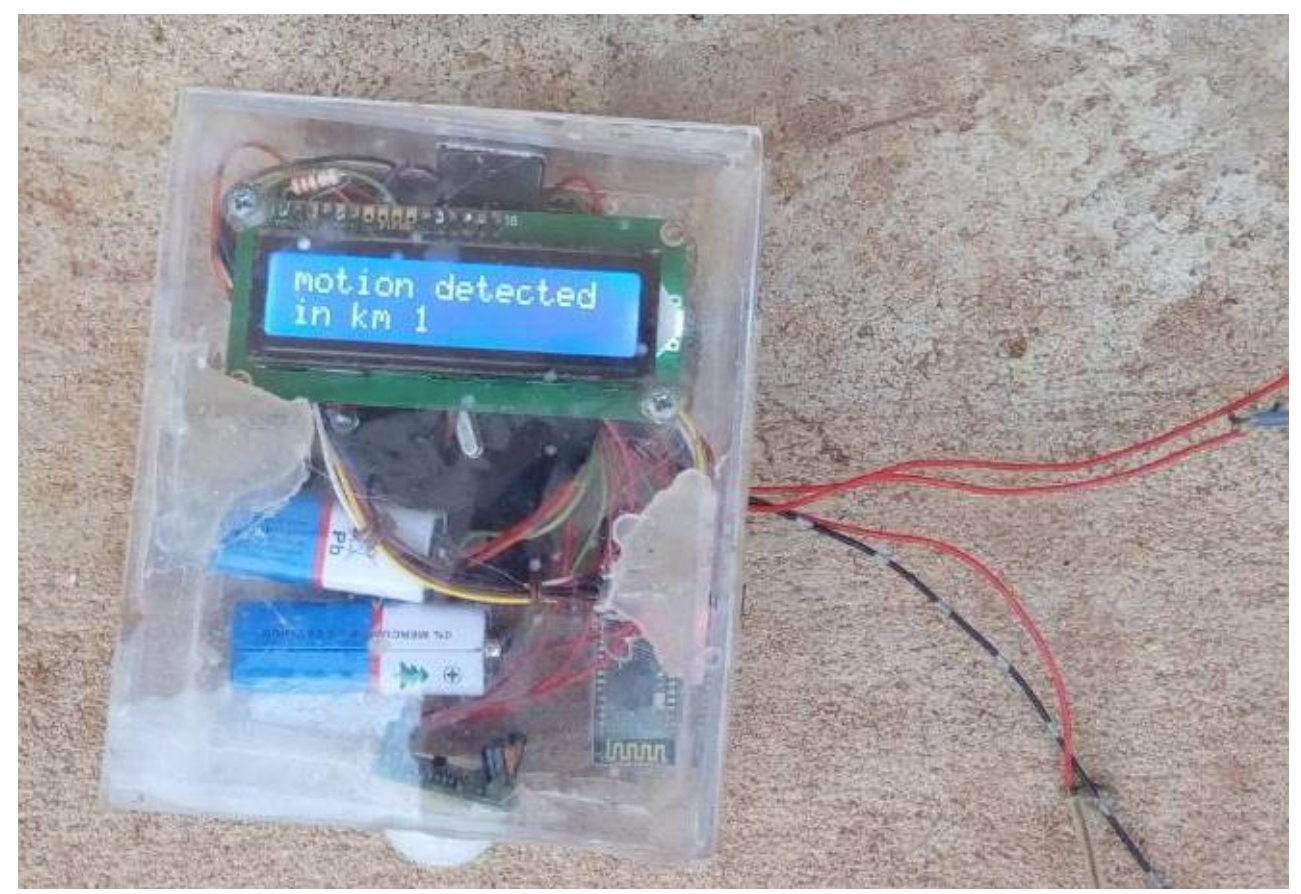

Figure 7: Complete designed prototype packaged in a case

The system produced results that met the system specifications and the entire system objectives. The indicator and the alarm continue to indicate a breakage at the sensor until it is noticed at the control room.

\section{Conclusion}

In this paper, a monitoring system for petroleum pipeline spillage detection system was proposed. The system takes into account a wiring sensor to provide a continuous electrical path to break the signal path and trigger an alarm at the base station to notify monitoring teams in the event of a break in the system configuration. The guards of monitoring represent the crossing conditions, these conditions are timer based as it sends signals with any detection of intrusion. The current work is devoted to increased efficiency in petroleum pipeline monitoring, increased government revenue as a result of the reduction in spillages, increased agricultural yields, salvage the ecosystem and reduce the effect of spillages on human lives. The wiring sensors used in this study can be incorporated into the pipeline design system to make it not too visible by covering it with resin to increase the reliability.

\section{References}

[1] F.O. Okorodudu., P.O. Okorodudu and K.O Ekerikvwe. "A model of petroleum pipeline spillage detection system for use in the Niger Delta region of Nigeria." International Journal of Research Granthaalayah, vol. 4, pp.1-16, Dec. 2016

[2] S. Ugwuanyi. "Nigeria loses N130m barrels of crude oil to 32 militant groups in 2011. Internet:Dailypost.ng/2016/11/29/Nigeria-loses-n130m-barrels-crude-oil-32-militant-groups2016, Nov. 29, 2016 [Jan. 17, 2017] 
[3] T. F. Balogun. "Mapping impacts of crude oil theft and illegal refineries on mangrove of the Niger Delta of Nigeria with remote sensing technology." Mediterranean Journal of Social Sciences, vol. 6, pp. 55 - 61, May, 2015

[4] R Okere. "Nigeria loses Africa's top producer position to Angola. Internet: t.guardian.ng/news/Nigeria-loses-africas-top-oil-producer-position-to-angola/, Apr. 18, 2017. [Jan. 10, 2017]

[5] Premium Times. "Vandals cut Nigeria's oil production by 800,000 barrels per day. Internet: http://www.premiumtimesng.com/news/top-news/203515-vandals-cut-nigerias-oil-production800000-barrels-per-day-kachikwu.html, May, 16, 2017 [Jan 15, 2017]

[6] The Nation Newspapers. "FG lost N2trn to militancy, pipeline vandalism in 2016. Internet: http://thenationonlineng.net/nigeria-lost-n2tn-militancy-pipeline-vandalism-nnpc-2/, Oct. 28, 2016 [Jan. 15, 2017].

[7] A.K. Adati. "Oil Exploration and Spillage in the Niger Delta of Nigeria." Civil and Environment Research, vol.2, pp.38 - 50, Apr. 2012.

[8] Africa practice. Nigeria: The Murky World of Oil Theft. Issue 137, Oct. 2012.

[9] United Nations Development Program. "Niger Delta Human Development Report". 2006, p. 15.

[10] Nigeria Delta Regional Development Master Plan, "The Niger Delta Region: Land and People. pp. $1-53,2006$

[11] S.M Kingdom and E.U Tahirih. "An appraisal on the role of the Nigeria security and civil defense corps in the reduction of vandalism of oil pipelines in the Niger Delta region." Journal of Environment and Earth Science, vol.4, pp. 2225 - 2248, Jun. 2014.

[12] Blood Trail: Repression and Resistance in Niger Delta. Civil Liberties Organization, Lagos, 2002, p. 9.

[13] L.F Awosika. "Impacts of global climate change and sea level rise on Coastal resources and energy development in Nigeria." In: Umolu, J.C., (Ed). Global Climate Change: Impact on Energy Development, 1995.

[14] United Nations Development Program. "Niger Delta Human Development Report". 2006, p. 44.

[15] Nigerian Security and Civil Defense Corps, (2013). Illegal Bunkering Activities in Delta State. Internet: www. interior.gov.ng/read-articles?-1 65, [Jan. 15, 2017]

[16] A.K. Adati., P. Z. Mohammad and O Fadhilah. (2012). "Oil spillage and pollution in Nigeria: Organizational management and institutional framework." Journal of Environment and Earth Science, vol.2, pp. 22-30, Apr. 2012.

[17] T Agbola and T.A Olurin. "Land use and land cover change in the Niger Delta", excerpts from a Research Report presented to the Centre for Democracy and Development, Aug. 2003.

[18] A Adewumi. "Pipeline vandalism: implications on economy. Economy. Internet: http://economicconfidential.com/2016/05/pipeline-vandalism-implications-economy/, Mar, 17. 2016 [Jan. 10, 2017]

[19] D Opeyemi. "Here's how the most recent pipeline vandalism will affect Nigeria. Internet: http://venturesafrica.com/heres-how-the-recent-pipeline-attacks-will-affect-nigeria/, Jan. 22. 2016, [Jan. 10, 2017]

[20] H.B. Odalonu. "The upsurge of oil theft and illegal bunkering in the Niger Delta region of Nigeria: Is there a way out?" Mediterranean Journal of Social Sciences, vol. 6, pp. 563-573, May. 2015

[21] F. O Okorodudu. "Development of a petroleum pipeline spillage detection system" unpublished $\mathrm{Ph} . \mathrm{D}$. thesis submitted to the department of Computer Science, Ebonyi State University, Abakaliki, Ebonyi State, Jul. 2017.

*Corresponding author.

E-mail address: okoroblackx4@ yahoo.co.uk 